\title{
Translation and cross-cultural adaptation of the Rating Scale for Countertransference (RSCT) to American English
}

\author{
Tradução e adaptação transcultural da Escala para Avaliação de \\ Contratransferência para a língua inglesa americana
}

Rafael Mondrzak, 1,2,4 Camila Reinert, 1,2,4 Andreia Sandri, ${ }^{1,2,4}$ Lucas Spanemberg, ${ }^{1,2}$ Eduardo L. Nogueira, ${ }^{1,2}$ Mirella Bertoluci, ${ }^{2}$ Claudio Laks Eizirik, ${ }^{3}$ Nina Rosa Furtado ${ }^{1,2,4}$

\begin{abstract}
Introduction: The Rating Scale for Countertransference (RSCT) - originally, Escala para Avaliação de Contratransferência (EACT) - is a self-administered instrument comprising questions that assess 23 feelings (divided into three blocs, closeness, distance, and indifference) that access conscious countertransferential emotions and sentiments. This paper describes the process of translation and cross-cultural adaptation of the RSCT into American English. Methods: This study employed the guidelines proposed by the International Society for Pharmacoeconomics and Outcomes Research (ISPOR) Task Force for Translation and Cultural Adaptation which define 10 steps for translation and cross-cultural adaptation of self-report instruments. Additionally, semantic equivalence tools were employed to select the final versions of terms used. The author of the RSCT gave permission for translation and took part in the process. The instrument is available for use free of charge.

Results: Analysis of the back-translation showed that just seven of the 23 terms needed to be adjusted to arrive at the final version in American English.

Conclusions: This study applied rigorous standards to construct a version of the RSCT in American English. This version of the RSCT translated and adapted into American English should be of great use for accessing and researching countertransferential feelings that are part of psychodynamic treatment.
\end{abstract}

Keywords: Rating Scale for Countertransference, translation, countertransference, scale.

\section{Resumo}

Introdução: A Escala para Avaliação de Contratransferência (EACT) é um instrumento autoaplicável composto por perguntas que avaliam 23 sentimentos (divididos em aproximação, em afastamento e em indiferença), que permite acessar os sentimentos contratransferenciais conscientes. Este trabalho descreve o processo de tradução e adaptação transcultural da EACT para a língua inglesa americana.

Métodos: O presente estudo utilizou a diretriz por força-tarefa proposta pela International Society for Pharmacoeconomics and Outcomes Research (ISPOR) que realiza em 10 passos a tradução e a adaptação transcultural de instrumentos autoaplicáveis. Além disso, ferramentas de equivalência semântica foram utilizadas para selecionar a versão final dos termos. 0 autor da EACT autorizou e participou do processo de tradução. O instrumento está disponível para uso gratuito.

Resultados: A avaliação da retrotradução mostrou que somente sete termos tiveram que ser ajustados para a realização da versão final na língua inglesa americana.

Conclusão: $O$ presente estudo construiu, segundo rígidos padrões, uma versão na língua inglesa americana da EACT. A versão traduzida e adaptada da EACT para a língua inglesa americana pode ser de grande utilidade para acessar e pesquisar sentimentos contratransferenciais que fazem parte do tratamento psicodinâmico.

Descritores: Escala para Avaliação de Contratransferência, tradução, contratransferência, escala.

\footnotetext{
${ }^{1}$ Departamento de Psiquiatria e Medicina Legal, Pontifícia Universidade Católica do Rio Grande do Sul (PUCRS), Porto Alegre, RS, Brazil. ${ }^{2}$ PUCRS, Porto Alegre, RS, Brazil. ${ }^{3}$ Universidade Federal do Rio Grande do Sul (UFRGS), Porto Alegre, RS, Brazil. ${ }^{4}$ Ambulatório de Psicoterapia Analítica (AMPA), Hospital São Lucas da PUCRS, Porto Alegre, RS, Brazil.

Financial support: none.

Submitted Nov 18 2015, accepted for publication Apr 18 2016. No conflicts of interest declared concerning the publication of this article.

Suggested citation: Mondrzak R, Reinert C, Sandri A, Spanemberg L, Nogueira EL, Bertoluci M, et al. Translation and cross-cultural adaptation of the Rating Scale for Countertransference (RSCT) to American English. Trends Psychiatry Psychother. 2016;38(4):221-226. http://dx.doi.org/10.1590/2237-6089-2015-0078
} 


\section{Introduction}

One of the most important concepts in the physicianpatient relationship in psychoanalysis is the phenomenon of countertransference (CT). The term was created by Freud and used for the first time in 1910 to refer to the therapist's unconscious emotions provoked by contact with the patient. ${ }^{1}$ Within this classic Freudian concept, CT was considered an obstacle that the physician needed to understand and overcome. ${ }^{2}$ However, in the 1950s, the psychoanalyst Paula Heimann introduced a wider definition of the concept that encompassed all of the emotional reactions that a therapist experiences in relation to their patient. $^{3}$

Nowadays, the classic and the totalist concepts have fused to form a single concept in which $\mathrm{CT}$ is seen as any internal experience of the therapist with relation to their patient, whether it is capable of facilitating or impeding psychotherapy. ${ }^{4}$ As the psychotherapeutic process evolved, it was found that CT is inherent to all settings because it encompasses both conscious and unconscious mechanisms. Countertransferential reactions that are inadequately managed can have a negative impact on the therapeutic process. ${ }^{5-7}$

Countertransference is a subjective and abstract phenomenon and one that is difficult to evaluate. ${ }^{8}$ A systematic review that was published recently assessed CT in psychotherapy of adults. A total of 25 studies were reviewed and they employed a total of 12 different instruments to assess CT, including, but not limited to, the Rating Scale for Countertransference (RSCT), Checklist of feelings, Countertransference Questionnaire, Countertransference Index, and the Inventory of Countertransference Behaviours. ${ }^{8}$ The majority of instruments used to assess CT are similar, comprising lists of feelings and scales that grade CT from absent to very intense. ${ }^{5}$ Studies in the field that have employed questionnaires to access countertransferential emotions have encountered certain limitations that are inherent to the construct, since they reduce the subjective experience to items or terms that simplify it. This reductionism can result in methodological problems, although use of these questionnaires enables studies to be replicated.

The RSCT was developed in 1997 with the objective of identifying therapists' emotional reactions to their patients in a sample of elderly patients. ${ }^{9}$ It is a selfadministered instrument, comprising 23 items that are subdivided into three categories of feelings: closeness, distance, and indifference. ${ }^{9}$ In a validation study, the RSCT was administered to 50 psychiatry residents after providing care to 131 patients who had been victims of trauma. The authors concluded that the scale is a trustworthy psychometric tool for accessing countertransferential emotions and that the instrument was particularly convenient because of its ease of applicability and comprehension. ${ }^{10}$

The RSCT has been used in several studies of CT in Brazilian samples, investigating $\mathrm{CT}$ and its association with patient characteristics in psychotherapy with an analytical orientation ${ }^{11} ; \mathrm{CT}$ and its demographic and clinical correlates in first consultations with women who had been the victims of sexual violence ${ }^{12}$; and CT and the therapeutic alliance at the start of psychodynamic psychotherapy. ${ }^{13}$ However, its applicability has hitherto been limited because it was developed in Portuguese, which hampered its adoption by researchers in other countries and its publication in international periodicals. A standardized translation in American English could therefore contribute to increasing the instrument's availability, enabling it to be tested and improved. It must be stressed that preservation of the developmental structure of the original scale is of fundamental importance to maintaining its reliability.

There are difficulties that affect any type of linguistic translation for scientific use. Much is lost in these processes, primarily semantic and functional content. In view of this, it is recommended that the translation process is approached in a universalist manner, that the existence of the concepts translated in the language of the target culture is ensured, and that a model of equivalence between the languages involved is constructed. ${ }^{14}$

The objective of this study was to conduct the process of translation and cross-cultural adaptation of the RSCT from its original Portuguese version to American English, employing standardized methodology.

\section{Methods}

\section{The Rating Scale for Countertransference (RSCT)}

The RSCT is a self-report instrument that comprises 23 questions assessing conscious countertransferential feelings. The items are measured using the Likert method (from $0=$ nothing to $3=$ strong) at three different points (at the start, during the consultation, and at the end) to capture the way in which these feelings vary during the session, and a mean score for the three points is calculated. The RSCT was developed by experienced analysts and psychotherapists with a great deal of psychoanalytic knowledge. A validation study conducted in 2012 concluded that the scale's items were capable 
of accessing conscious countertransferential feelings in psychiatry residents working with patients who had been the victims of trauma. ${ }^{10}$

The original Portuguese version of the scale is available for use free of charge.

The authors of the present study developed a version of the RSCT in American English, following recommendations published by the International Society for Pharmacoeconomics and Outcomes Research (ISPOR). These recommendations are commonly used in our field for translation and cross-cultural adaptation of self-report instruments. ${ }^{15,16}$

\section{Procedures}

Recommendations for procedures of translation and cross-cultural adaptation of scales drawn up by the Task Force for Translation and Cultural Adaptation of the ISPOR were followed.

There are 10 basic steps to be followed to conduct the translation ${ }^{17}$ :

1) Preparation: initial preparation of the instrument before the translation process;

2) Forward translation: first translation from source language to the desired target language;

3) Reconciliation: comparison and merging of different translations into a single version;

4) Back-translation: translation of the reconciled version from the target language back to the source language;

5) Back-translation review: review of discrepancies between the original version and the version produced by back-translation;

6) Harmonization: comparison of multiple backtranslated versions with each other and with the original version of the scale to harmonize discrepancies;

7) Cognitive debriefing: administration of the instrument to a small number of physicians (in the case of this project) to assess comprehension, interpretation and the cultural relevance of the translation;

8) Review of cognitive debriefing results and finalization;

9) Proofreading; and

10) Final Report.

The author of the original version of the instrument approved this project and participated directly in it.

The "forward translations" were performed by three qualified translators, two of whom were native speakers of the target language and had recognized experience with scientific publications on medical subjects. Their translations were produced independently and resulted in three different initial versions.
The Reconciliation step was conducted by people fluent in the target language who were not involved in the forward translations and did not include the author of the original version.

The back-translation was produced by three duly qualified and independent translators, who were unconnected to the project and were not familiar with the original instrument in its source language or the first translations. The final review of the backtranslation was conducted by the author of the original scale together with the other authors of this paper.

For the cognitive debriefing, two psychiatrists whose mother tongue was English and one Brazilian psychiatrist with advanced proficiency in English completed the scale. All three had good knowledge of the psychodynamic approach and mastery of the concept of CT and its applications in clinical practice as a tool in psychotherapy. Each therapist agreed to complete the scale twice, for two different patients, in order to enable assessment from the point of view of: comprehension, interpretation, and the cultural relevance of the translation. The basic tool used to standardize the assessments was a chart with data and characteristics to be described relating to the scale.

In order to arrive at a final version of the instrument, the terms were analyzed according to the three principal criteria of equivalence: conceptual, semantic, and functional. ${ }^{14}$ First, consideration was given to conceptual equivalence between terms with relation to the sociocultural features of the population in the target language of application. Next, the semantic equivalence of the terms in the two languages was compared to avoid any changes in meaning. The terms should be unaltered stylistically and in terms of connotations. Finally, the functional equivalence of the terms in the target language was tested. In this step the terms were tested in order to enable us to fulfill the primary objective of the scale: capture the countertransferential feelings of the therapist who completed the scale.

\section{Results}

Table 1 lists the original terms, the three initial translations into English, the Reconciliation, the back-translation and the final version. After the back-translation review, seven of the 23 terms had to be reassessed because of discrepancies with the terms used in the original scale: a) preocupação; b) compaixão; c) constrangimento; d) desaprovação; e) raiva; f) falta de preocupação; and g) ausência. 
Table 1 - Original version, translations, reconciliation, back-translation and final version of the Rating Scale for Countertransference (RSCT)

\begin{tabular}{|c|c|c|c|c|c|c|}
\hline Original & Translation (1) & Translation (2) & Translation (3) & Reconciliation & Back-translation & Final version \\
\hline Curiosidade & Inquisitiveness & Curiosity & Inquisitiveness & Curiosity & Curiosidade & Curiosity \\
\hline Interesse & Concern & Interest & Involvement & Interest & Interesse & Interest \\
\hline Simpatia & Appreciation & Rapport & Concern & Concern & Preocupação* & Concern \\
\hline Solidariedade & Sympathy & Solidarity & Sympathy & Sympathy & Solidariedade & Sympathy \\
\hline Afeição & Affection & Caring & Affection & Affection & Afeição & Affection \\
\hline Desejo de ajudar & Helpful & Willingness to help & Promptness & Willingness to help & Desejo de Ajudar & Willingness to help \\
\hline Alegria & Joy & Joyfulness & Cheer & Joyfulness & Alegria & Joyfulness \\
\hline Tristeza & Grief & Sadness & Despondency & Sadness & Tristeza & Sadness \\
\hline Pena & Compassion & Commiseration & Compassion & Compassion & Compaixão* & Compassion \\
\hline Atração & Attraction & Attraction & Appeal & Attraction & Atração & Attraction \\
\hline Desconforto & Inconvenience & Uneasiness & Embarrassment & Embarrassment & Constrangimento* & Embarrassment \\
\hline Desconfiança & Skepticism & Mistrust & Mistrustfulness & Mistrustfulness & Desconfiança & Mistrustfulness \\
\hline Tédio & Tedium & Boredom & Apathy & Boredom & Tédio & Boredom \\
\hline Rejeição & Rejection & Rejection & Rebuff & Rejection & Rejeição & Rejection \\
\hline Desesperança & Despair & Hopelessness & Disheartenment & Hopelessness & Desesperança & Hopelessness \\
\hline Reprovação & Disapproval & Disapproval & Dislike & Disapproval & Desaprovação* & Disapproval \\
\hline Acusação & Indictment & Accusation & Accusation & Accusation & Acusação & Accusation \\
\hline Irritação & Anger & Annoyance & Exacerbation & Anger & Raiva* & Anger \\
\hline Medo & Fear & Fear & Intimidation & Fear & Medo & Fear \\
\hline Hostilidade & Hostility & Hostility & Unfriendliness & Hostility & Hostilidade & Hostility \\
\hline Desinteresse & Apathy & Lack of concern & Apathy & Lack of concern & Falta de preocupação* & Lack of concern \\
\hline Distância & Absence & Aloofness & Detachment & Absence & Ausência* & Absence \\
\hline Imobilidade & Immobility & Immobility & Apathy & Immobility & Imobilidade & Immobility \\
\hline
\end{tabular}

* Terms reassessed because of discrepancies with the terms used in the original scale.

Since there are no versions of the RSCT in other languages, the stage of harmonization and comparison with other versions in back-translation was not performed.

The final version of the scale is shown in Figure 1.

\section{Discussion}

This paper described the process of translation and cross-cultural adaptation of the RSCT into English, using the method recommended by the ISPOR's Task Force for Translation and Cultural Adaptation. ${ }^{17}$ This is the first translation of this instrument conducted to date.

According to Herdman et al., writing in 1998, a universalist approach should be used when dealing with cross-cultural research, involving assessment of and respect for cultural differences. ${ }^{14}$ Translation of the RSCT followed a standardized process and seven adaptations were needed.

During the process of choosing terms for the final version, 16 of the 23 terms were translated easily because there was no disagreement between the term used in the original version when compared with the back-translation. Seven terms needed reassessment to ensure that they maintained the three criteria of semantic equivalence proposed methodologically and did not acquire different emotional meanings in English to those used in the original version. These terms were discussed internally among the authors of this article and two translators who took part in the translation process.

It is worth mentioning the difficulties involved when dealing with a scale for accessing countertransferential feelings. The subjectivity of the concept of CT (open to multiple interpretations), the unconscious functioning of $\mathrm{CT}$, and the varying definitions of the concept throughout the history of psychoanalysis raise problems for this research and could limit it. Another difficulty that was encountered during the study was caused by semantic clashes between the two languages: it is known that however much care is taken when undertaking a translation, concepts, definitions, and the individual characteristics of a language can be lost in translation.

Future adaptation into other languages should follow the same process and should be compared with the back-translated version in this article. It should also be stressed that future translations and adaptations should primarily be conducted in countries in which English is the first language.

The small number of translators could be a limitation of this study and reduce the reliability of the translation. Since there are no versions of the RSCT in other languages, harmonization and comparison with the back-translated version were not conducted. This limitation could be overcome by translating the instrument into a third language and then performing these procedures. 


\section{RATING SCALE FOR COUNTERTRANSFERENCE (RSCT)}

Step 1: Instructions: Evaluate whether, during the interview, you experienced any of the feelings below relative to the respondent. Make a circle around the number that best expresses your feeling.

Check the sub-totals

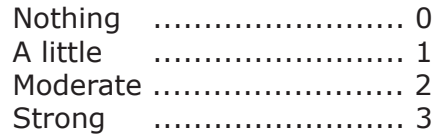

\begin{tabular}{|llll|}
\hline & At first & During & At the end \\
\hline Curiosity & 0123 & 0123 & 0123 \\
\hline Interest & 0123 & 0123 & 0123 \\
\hline Concern & 0123 & 0123 & 0123 \\
\hline Sympathy & 0123 & 0123 & 0123 \\
\hline Affection & 0123 & 0123 & 0123 \\
\hline Willingness to help & 0123 & 0123 & 0123 \\
\hline Joyfulness & 0123 & 0123 & 0123 \\
\hline Sadness & 0123 & 0123 & 0123 \\
\hline Compassion & 0123 & 0123 & 0123 \\
\hline Attraction & 0123 & 0123 & 0123 \\
\hline \hline & At first & During & At the end \\
\hline Embarrassment & 0123 & 0123 & 0123 \\
\hline Mistrustfulness & 0123 & 0123 & 0123 \\
\hline Boredom & 0123 & 0123 & 0123 \\
\hline Rejection & 0123 & 0123 & 0123 \\
\hline Hopelessness & 0123 & 0123 & 0123 \\
\hline Disapproval & 0123 & 0123 & 0123 \\
\hline Accusation & 0123 & 0123 & 0123 \\
\hline Anger & 0123 & 0123 & 0123 \\
\hline Fear & 0123 & 0123 & 0123 \\
\hline Hostility & 0123 & 0123 & 0123 \\
\hline At first & During & At the end \\
\hline Embarrassment & 0123 & 0123 & 0123 \\
\hline Mistrustfulness & 0123 & 0123 & 0123 \\
\hline Boredom & 0123 & 0123 & 0123 \\
\hline
\end{tabular}

Figure 1 - final Version of the instrument in English.

\section{Conclusions}

The original version of the RSCT was translated and adapted into American English following rigorous international standards. The instrument is already available for use, although validation is still ongoing and will be the subject of future studies.

We believe that this instrument should be especially useful for assessment of conscious countertransferential feelings. Additionally, its translation into English should not only facilitate its use in other countries, it should also facilitate its translation into additional languages.

\section{References}

1. Eizirik CL, Costa F, Kapczinski F, Pilcher R, Gauer R, Liberman Z. Observing countertransference in brief dynamic psychotherapy. Psychother Psychosom. 1991;56:174-81.

2. Sigmund $F$. As perspectivas futuras da terapêutica psicanalítica. In: Cinco lições de psicanálise, Leonardo Da Vinci e outros trabalhos. Vol. 11. Porto Alegre: Imago; 1910. p. 147-56.

3. Rossberg JI, Karterud S, Pedersen G, Friis S. Specific personality traits evoke different countertransference reactions: an empirical study. J Nerv Ment Dis. 2008;196:702-8.

4. McIntyre SM, Schwartz RC. Therapists' differential countertransference reactions toward clients with major depression or borderline personality disorder. J Clin Psychol. 1998; 54:923-31.

5. Rosenberger EW, Hayes JA. Therapist as subject: a review of the empirical countertransference literature. J Couns Dev. 
2002;80:264-70.

6. Gabbard GO. A comtemporary psychoanalytic model of countertransference. J Clin Psychol. 2001;57:983-91.

7. Betan E, Heim AK, Zittel Conklin C, Westen D. Countertransference phenomena and personality pathology in clinical practice: an empirical investigation. Am J Psychiatry. 2005;162:890-8.

8. Machado Dde B, Coelho FM, Giacomelli AD, Donassolo MA, Abitante MS, Dall'Agnol T, et al. Systematic review of studies about countertransference in adult psychotherapy. Trends Psychiatry Psychother. 2014;36:173-85.

9. Eizirik CL. Rede social, estado mental e contratransferência: estudo de uma amostra de velhos da região urbana de Porto Alegre. Porto Alegre: Universidade Federal do Rio Grande do Sul (UFRGS); 1997.

10. Silveira Júnior Ede M, Polanczyk GV, Eizirik M, Hauck S, Eizirik $\mathrm{CL}$, Ceitlin LH. Trauma and countertransference : development and validity of the Assessment of Countertransference Scale (ACS). Rev Bras Psiquiatr. 2012;34:201-6.

11. Grudtner RR. Estudo da contratransferência e sua associação com características do paciente em psicoterapia de orientação analítica. Porto Alegre: UFRGS; 2009.

12. Eizirik M, Schestatsky S, Kruel L, Ceitlin LHF. Contratransferência no atendimento inicial de mulheres vítimas de violência sexual. Rev Bras Psiquiatr. 2011;33:16-22.

13. Machado Dde B, Teche SP, Lapolli C, Tavares BF, de Almeida LS, da Silva GB, et al. Countertransference and therapeutic alliance in the early stage of adult psychodynamic psychotherapy. Trends Psychiatry Psychother. 2015;37:133-42.
14. Herdman M, Fox-Rushby J, Badia X. A model of equivalence in the cultural adaptation of HRQoL instruments: the universalist approach. Qual Life Res. 1998;7:323-35.

15. Baeza FL, Caldieraro MA, Pinheiro DO, Fleck MP. Translation and cross-cultural adaptation into Brazilian Portuguese of the Measure of Parental Style (MOPS) - a self-reported scale according to the International Society for Pharmacoeconomics and Outcomes Research (ISPOR) recommendations. Rev Bras Psiquiatr. 2010;32:159-63.

16. Spanemberg L, Parker G, Caldieraro MA, Vares EA, Costa F, Costa MM, et al. Translation and cross-cultural adaptation of the Temperament \& Personality Questionnaire into Brazilian Portuguese. Trends Psychiatry Psychother. 2014;36:214-8.

17. Wild D, Grove A, Martin M, Eremenco S, McElroy S, VerjeeLorenz $A$, et al. Principles of good practice for the translation and cultural adaptation process for Patient-Reported Outcomes (PRO) measures: report of the ISPOR task force for translation and cultural adaptation. Value Health. 2005;8:94-104.

\section{Correspondence:}

Rafael Mondrzak

Rua Alvares Machado, 44/404

90630-010 - Porto Alegre, RS - Brazil

Tel.: + 55 (51) 99962.8822

E-mail: mondrzak@hotmail.com 